\title{
PENGARUH KEPRIBADIAN, PROFESIONALISME DAN PENGALAMAN MENGAJAR TERHADAP KINERJA GURU MADRASAH TSANAWIYAH NEGERI 2 MANDAILING NATAL
}

\author{
${ }^{1}$ Ibrahim, ${ }^{2}$ Wahyu Suryo Wibowo, ${ }^{3}$ Irwan Hengki Sukma, ${ }^{4}$ Yogie Pratama, ${ }^{5}$ Yudi Caesario \\ ${ }_{1,2,3,4,5}$ Universitas Islam Sumatera Utara \\ ${ }^{1}$ ibrahim.mm@gmail.com, ${ }^{2}$ wahyu.suryowibowo@gmail.com, ${ }^{3}$ irwanhengki.sukma@gmail.com, \\ ${ }^{4}$ yogie.pratama@gmail.com, 5 yudi.caesario@gmail.com
}

\begin{abstract}
The formulation in this research is how the personality influence, professionalism and experience teaching to the performance of teachers of the state of Tsanawiyah Madrasah 2 Mandailing Natal, and the purpose of this research is to know and analyze The influence of personality, professionalism and experience teaching to the performance of teachers of State Madrasah Tsanawiyah 2 Mandailing Natal. This research is a quantitative descriptive study. Data collection techniques are conducted through interviews, inquiry lists and documentation studies. The samples in this study were as many as 36 teachers. Variables are measured at Likert scale. Hypothesis testing using multiple linear regression analyses through $F$-test and T-Test. The results of the test in unison showed that the personality, professionalism and experience demonstrated a very noticeable influence on the performance of teachers of state Madrasah Tsanawiyah 2 Mandailing Natal with a value $F_{\text {count }} 24,804>F_{\text {table }} 2.87$ and significance value of $0.000^{b}$. Adjusted number of $R$ Square by 0.671 or $(67.1 \%)$ indicates that the percentage of contribution of independent variable influence (personality, professionalism and teaching experience) to the dependent variable (teacher performance) amounted to $67.1 \%$. Partially, personality positively affects the performance of Guru Madrasah Tsanawiyah Negeri 2 Mandailing Natal with a value of $t_{\text {count }}>$ $t_{\text {table }}(2,988>2,028)$ and significance value of 0. 005. Professionalism positively and significantly influence the teacher's performance of state Madrasah Tsanawiyah 2 Mandailing Natal with a value of $t_{\text {count }}>t_{\text {table }}(2,728<2,028)$ and a significance value of 0.010 . The teaching experience has positive and significant effect on the teacher's performance of Negeri Tsanawiyah 2 Mandailing Natal with a value of $t_{\text {count }}>t_{\text {table }}(4,580>2,028)$ and a significance value of 0.000. The highest value of a regression coefficient is the teaching Experience $\left(X_{3}\right)$ of 0.532 or $53.2 \%$ and is the most dominant variable affecting the teacher's performance of Negeri 2 Mandailing Natal.
\end{abstract}

Keywords: Personality, Professionalism, Teaching Experience, Teacher Performance.

ABSTRAK : Rumusan pada penelitian ini adalah bagaimana pengaruh kepribadian, profesionalisme dan pengalaman mengajar terhadap kinerja guru Madrasah Tsanawiyah Negeri 2 Mandailing Natal, dan tujuan penelitian ini adalah untuk mengetahui dan menganalisis pengaruh kepribadian, profesionalisme dan pengalaman mengajar terhadap kinerja guru Madrasah Tsanawiyah Negeri 2 Mandailing Natal. Penelitian ini merupakan penelitian deskriptif kuantitatif. Teknik pengumpulan data dilakukan melalui wawancara, daftar pertanyaan dan studi dokumentasi. Sampel dalam penelitian ini sebanyak 36 orang pegawai. Variabel diukur dengan skala Likert. Pengujian hipotesis menggunakan analisis regresi linear berganda melalui uji $F$ dan uji t. Hasil uji secara serempak menunjukkan bahwa Kepribadian, profesionalisme dan pengalaman menunjukkan pengaruh sangat nyata terhadap kinerja guru Madrasah Tsanawiyah Negeri 2 Mandailing Natal dengan nilai $F_{\text {hitung }} 24.804>F_{\text {tabel }} 2.87$ dan nilai signifikansi sebesar $0.000^{b}$. Angka Adjusted $R$ Square sebesar 0.671 atau $(67,1 \%)$ menunjukkan bahwa persentase sumbangan pengaruh variabel independen (kepribadian, profesionalisme dan pengalaman mengajar) terhadap variabel dependen (kinerja guru) sebesar 67,1\%. Secara parsial, kepribadian berpengaruh positif terhadap kinerja guru Madrasah Tsanawiyah Negeri 2 Mandailing Natal 
dengan nilai $t_{\text {hitung }}>t_{\text {tabel }}(2.988>2.028)$ dan nilai signifikansi sebesar 0.005. Profesionalisme berpengaruh positif dan signifikan terhadap kinerja guru Madrasah Tsanawiyah Negeri 2 Mandailing Natal dengan nilai $t_{\text {hitung }}>t_{\text {tabel }}(2.728<2.028)$ dan nilai signifikansi sebesar 0.010. Pengalaman mengajar berpengaruh positif dan signifikan terhadap kinerja guru Madrasah Tsanawiyah Negeri 2 Mandailing Natal dengan nilai $t_{\text {hitung }}>t_{\text {tabel }}(4.580>2.028)$ dan nilai signifikansi sebesar 0.000. Nilai koefisien regresi yang paling tinggi adalah pengalaman mengajar $\left(X_{3}\right)$ sebesar 0.532 atau 53,2\% dan merupakan variabel yang paling dominan mempengaruhi kinerja guru Madrasah Tsanawiyah Negeri 2 Mandailing Natal.

\section{Kata kunci: Kepribadian, Profesionalisme, Pengalaman Mengajar, Kinerja Guru.}

\section{Pendahuluan}

Pendidikan mempunyai peranan yang sangat strategis dalam pembangunan suatu bangsa. Pendidikan merupakan salah satu kebutuhan manusia, yang bertujuan untuk membentuk manusia yang baik dan berbudi luhur menurut cita-cita dan nilai-nilai dari masyarakat serta untuk mencerdaskan kehidupan bangsa. Pendidikan mampu memfasilitasi perubahan demi terwujudnya pendidikan yang merata, bermutu, dan relevan dengan kebutuhan masyarakatnya. Pendidikan membutuhkan sumber daya yang mendukung dan menunjang pelaksanaannya agar tujuan pendidikan dapat tercapai. Dengan sumber daya manusia yang baik maka sebuah institusi pendidikan akan berkembang secara optimal sebagaimana yang diharapkan. Guru adalah orang yang memberikan ilmu pengetahuan kepada anak didik. Guru dalam pandangan masyarakat adalah orang yang melaksanakan pendidikan di tempat tertentu, tidak mesti di lembaga pendidikan formal, tetapi bisa juga di masjid, surau, mushala, rumah, dan sebagainya.

Maka guru di zaman sekarang sudah mendapat arti yang luas lagi dalam masyarakat. Semua orang yang pernah memberikan suatu ilmu atau kepandaian tertentu kepada seseorang atau sekelompok orang dapat disebut guru, misalnya: guru silat, guru senam, guru mengaji, guru menjahit, dan sebagainya. Namun dalam pembahasan berikutnya, guru yang dimaksud adalah seseorang yang mengajar di sebuah lembaga pendidikan, terutama di sekolah/sekolahalah orang yang memberikan ilmu pengetahuan kepada anak didik. Guru dalam pandangan masyarakat adalah orang yang melaksanakan pendidikan di tempat tertentu, tidak mesti di lembaga pendidikan formal, tetapi bisa juga di masjid, surau, mushala, rumah, dan sebagainya. Maka guru di jaman sekarang sudah mendapat arti yang luas lagi dalam masyarakat. Semua orang yang pernah memberikan suatu ilmu atau kepandaian tertentu kepada seseorang atau sekelompok orang dapat disebut guru, misalnya: guru silat, guru senam, guru mengaji, guru menjahit, dan sebagainya. Namun dalam pembahasan berikutnya, guru yang dimaksud adalah seseorang yang mengajar di sebuah lembaga pendidikan. Guru adalah sosok yang menempati posisi dan memegang peran penting dalam pendidikan. Guru merupakan salah satu factor penentu tinggi rendahnya mutu hasil pendidikan. Sehingga, guru dituntut untuk meningkatkan kualitas dalam melaksanakan tugasnya agar memiliki kinerja yang tinggi, Mulyasa (2013:101).

Kinerja dipengaruhi oleh faktor eksternal dan faktor internal, dimana faktor internal yaitu dorongan untuk bekerja, tanggung jawab terhadap tugas, dan minat terhadap tugas. Sedangkan faktor eksternal yaitu penghargaan atas tugas, peluang untuk berkembang, perhatian dari kepala sekolah, hubungan interpersonal sesama guru, adanya pelatihan, kelompok diskusi terbimbing, dan layanan perpustakaan. Kinerja guru merupakan kegiatan guru dalam proses pembelajaran yaitu bagaimana guru merencanakan pembelajaran, melaksanakan kegiatan pembelajaran, dan menilai serta mengevaluasi pembelajaran. Kinerja guru merupakan kemampuan seorang guru dalam melaksanakan tugas pembelajaran di sekolah atau sekolah dan bertanggung jawab atas peserta didik di bawah bimbingannya dengan meningkatkan prestasi belajar peserta didik, Supardi (2014:54).

Kinerja guru juga dapat ditunjukkan dari seberapa besar kompetensi- kompetensi yang dipersyaratkan dipenuhi. Kompetensi tersebut meliputi kompetensi pedagogik, kompetensi kepribadian, kompetensi sosial dan kompetensi profesional" (Undang - Undang No. 14 Tahun 2005 tentang guru dan dosen). Keempat kompetensi guru ini merupakan satu kesatuan yang menggambarkan sosok utuh guru 
sebagai tenaga profesi dalam bidang pendidikan.

Berdasarkan survei awal yang peneliti lakukan di Madrasah Tsanawiyah Negeri 2 Mandailing Natal, dapat penulis kemukakan bahwa faktor uang diduga berpengaruh terhadap kinerja guru adalah pengalaman mengajar guru. Pengalaman merupakan segala sesuatu yang telah dialami dalam hidup. pengalaman yang semakin tinggi dan semakin sering seseorang melakukan pekerjaan yang sama, maka semakin terampil dan semakin cepat dalam menyelesaikan pekerjaan tersebut. Semakin banyak macam pekerjaan yang dilakukan seseorang, pengalaman kerjanya semakin kaya dan luas, serta memungkinkan peningkatan kinerja, Faustino (2011:197). Dengan demikian, pengalaman yang diperoleh guru selama mengajar di sekolah tentu akan sangat berpengaruh dalam suatu pencapaian hasil. Semakin tinggi pengalaman mengajar seorang guru, maka semakin baik pula kemampuannya dalam mengajar.

Pengalaman mengajar yang dimiliki oleh seorang guru menjadi pencapaian hasil belajar yang akan diraih oleh siswa. Guru yang mempunyai pengalaman mengajar yang memadai secara positif akan mendukung kinerjanya di sekolah. Semakin banyak pengalaman mengajar guru, semakin banyak pula pengetahuan yang dimiliki seorang guru. Semakin bertambah masa kerjanya, guru diharapkan semakin banyak pengalaman serta pengetahuannya. Hasil pengamatan, kinerja guru di Madrasah Tsanawiyah Negeri 2 Mandailing Natal belum sesuai dengan harapan, antara lain dalam hal pengalaman guru, masih ada guru yang enggan untuk meningkatkan kemampuan profesionalnya, sehingga aktivitas pembelajaran di kelas monoton dan kurang berkembang, kinerja guru dalam melaksanakan tugas mengajar di kelas masih belum optimal, aktifitas guru dalam mengikuti temu ilmiah masih kurang, partisipasi guru dalam kelompok kerja guru/ pemantapan kerja guru, musyawarah guru mata pelajaran/ bidang studi masih kurang. Pembinaan kepala sekolah kepada guru juga terlihat belum optimal, antara lain kurang diberi kesempatan kepada guru-guru untuk mengembangkan kemampuan profesionalnya, misalnya mengikuti pendidikan dan pelatihan dan lain sebagainya

Selanjutnya guru yang memiliki kinerja yang baik dan profesional dalam implementasi kurikulum memiliki ciri-ciri mampu mendesain program pembelajaran, melaksanakan pembelajaran dan menilai hasil pembelajaran peserta didik dengan baik dan benar. Sikap profesional guru yang baik tercermin dari pribadi yang baik pula, hal tersebut erat kaitannya dengan kompetensi guru yaitu kompetensi kepribadian. Empat kometensi guru (kepribadian, pedagogik, sosial, dan profesional) menjadi salah satu syarat seorang guru dapat dikatakan profesional. Profesionalisme guru seyogyanya menjadi springboard bagi guru untuk terus menerus menata komitmen melakukan perbaikan diri dalam rangka meningkatkan kinerjanya. Peningkatan kinerja atas dorongan iklim organisasi yang baik diharapkan mampu meningkatkan efektivitas dan efisiensi kinerja guru di sekolah.

Sejalan dengan peningkatan kinerja guru, sikap seorang guru yang baik dan sesuai norma juga hendaknya dilakukan dalam setiap perbuatan. Hubungan baik dengan pemimpin (kepala sekolah), sesama guru, dan tata usaha dalam lingkungan sekolah merupakan salah satu penerapannya. Selain itu, keberadaan sarana dan prasarana yang menunjang pelaksanaan kerja guru mutlak diperlukan demi kelancaran pelaksanaan tugas. Oleh karena itu berdasarkan pemaparan tersebut, kita perlu mengetahui lebih dalam tentang profesionalisme guru di Madrasah Tsanawiyah Negeri 2 Mandailing Natal.

Secara umum kriteria utama yang harus dimiliki oleh seorang guru yakni kemampuan (ability), kepribadian (personality), motivasi (motivation) dan komitmen (commitment). Keempat kriteria tersebut dinilai akan mempengaruhi kinerja seorang guru dalam melaksanakan tugasnya. Adapun kendala yang ditemukan pada kriteria di atas adalah kepribadian guru. Sebagian guru masih memiliki kepribadian yang kurang sesuai dengan profesionalisme guru. Seperti masih dilihat adanya sebagian guru yang masih sulit mengendalikan emosi, kurang memperhatikan siswa, kurang respon terhadap masalah yang dihadapi siswa dalam belajar, dan kurang komunikatif. Faktor kepribadian guru yang masih kurang itu juga terlihat dari adanya guru yang menunjukkan perilaku pribadi yang negatif, seperti kurang ramah, terlalu santai, kurang peka terhadap lingkungan, kurang percaya diri, dan agak malas. 
Kendala-kendala pada kepribadian ini, tentu saja mempengaruhi kinerja guru Madrasah Tsanawiyah Negeri 2 Mandailing Natal dalam menjalankan tugasnya. Hal ini terlihat dari adanya guru yang kurang efisien dalam bekerja, kurang teliti, kurang kreatif, dan pada akhirnya hasil yang dicapai dalam bertugas pun kurang maksimal. Sebagian guru terlihat kurang mampu menyusun desain perangkat pengajaran dengan baik, kurang menguasai metode mengajar yang sesuai, kurang mampu melakukan interaksi dengan siswa, kualitas dan kuantitas hasil kerja juga terbatas pada hal-hal yang sudah ditentukan saja. Kurang kreatifitas dalam menghasilkan hal-hal baru yang mendukung program pembelajaran, seperti membuat buku, menyiapkan alat peraga, dan lain-lain. Kinerja yang kurang ini sedikit banyak tentu dipengaruhi oleh faktor kepribadian guru.

\subsection{Batasan Masalah}

Agar permasalahan yang dikaji terarah maka permasalahan dibatasi sebagai berikut. Penelitian ini akan mengkaji tentang kinerja guru namun dalam penelitian ini hanya membahas faktor kepribadian, profesionalisme dan pengalaman mengajar yang secara bersama-sama memberikan kontribusi ataupun tidak terhadap kinerja guru baik secara partial maupun secara simultan.

\subsection{Hioptesis}

Hipotesis dalam penelitian ini adalah sebagai berikut :

1) Kepribadian berpengaruh positif dan signifikan terhadap kinerja guru Madrasah Tsanawiyah Negeri 2 Mandailing Natal.

2) Profesionalisme berpengaruh positif dan signifikan terhadap kinerja guru Madrasah Tsanawiyah Negeri 2 Mandailing Natal.

3) Pengalaman mengajar berpengaruh positif dan signifikan terhadap kinerja guru Madrasah Tsanawiyah Negeri 2 Mandailing Natal.

4) Kepribadian, profesionalisme dan pengalaman mengajar berpengaruh positif dan signifikan terhadap kinerja guru Madrasah Tsanawiyah Negeri 2 Mandailing Natal.

\subsection{Tujuan Penelitian}

Tujuan penelitian ini adalah :

1) Untuk mengetahui dan menganalisis pengaruh kepribadian terhadap kinerja guru
Madrasah Tsanawiyah Negeri 2 Mandailing Natal.

2) Untuk mengetahui dan menganalisis pengaruh profesionalisme terhadap kinerja guru Madrasah Tsanawiyah Negeri 2 Mandailing Natal.

3) Untuk mengetahui dan menganalisis pengaruh pengalaman mengajar terhadap kinerja guru Madrasah Tsanawiyah Negeri 2 Mandailing Natal.

4) Untuk mengetahui dan menganalisis pengaruh kepribadian, profesionalisme dan pengalaman mengajar terhadap kinerja guru Madrasah Tsanawiyah Negeri 2 Mandailing Natal.

\section{Metode Penelitian \\ 2.1.Populasi dan Sampel}

Berdasarkan data guru bahwa populasi dalam penelitian ini adalah seluruh guru Madrasah Tsanawiyah Negeri 2 Mandailing Natal yang berjumlah 36 orang. Dalam hal ini kepala madrasah dan peneliti tidak dijadikan populasi, dengan rincian sebagai berikut :

Tabel 1. Kerangka Populasi Guru

\begin{tabular}{|c|l|c|}
\hline No & \multicolumn{1}{|c|}{ Keterangan } & $\begin{array}{c}\text { Jumlah } \\
\text { Guru }\end{array}$ \\
\hline 1 & Guru tetap & 26 \\
\hline 2 & Guru honorer & 10 \\
\hline \multicolumn{2}{|c|}{ Jumlah } & $\mathbf{3 6}$ \\
\hline
\end{tabular}

Sumber: M.Ts. Negeri 2 Mandailing Natal, 2020

Penelitian ini menggunakan teknik pengambilan sampel nonprobability sampling (sampling jenuh). Sampling jenuh atau sensus adalah teknik penentuan sampel bila semua anggota populasi digunakan sebagai sampel. Jadi jumlah guru Madrasah Tsanawiyah Negeri 2 Mandailing Natal yang ada yaitu 36 orang semua menjadi sampel. Hal ini sering dilakukan bila jumlah populasi relatif kecil, atau penelitian yang ingin membuat generalisasi dengan kesalahan yang sangat kecil.

\subsection{Uji Normalitas}

Uji normalitas bertujuan untuk menguji apakah dalam model regresi variabel pengganggu (residual) memiliki distribusi normal. Seperti diketahui bahwa uji "t" dan uji F mengasumsikan bahwa nilai residual mengikuti distribusi normal.

Dalam penelitian ini pengujian normalitas dideteksi melalui analisa grafik P-P Plot.yang dihasilkan melalui SPSS. Adapun output grafik 
P-P Plot seperti terlihat pada gambar dibawah ini:

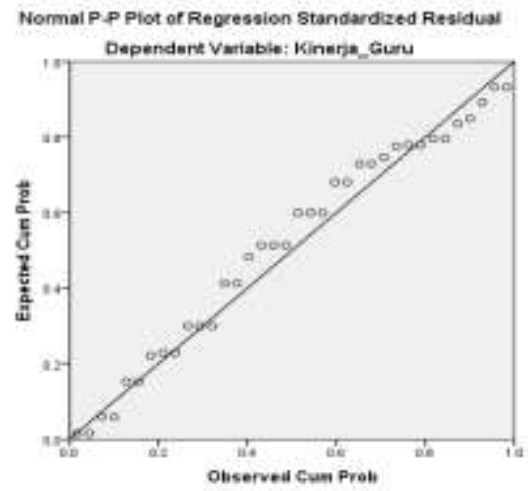

Gambar 1. Uji normalitas P-P Plot Test

Berdasarkan gambar 1 di atas, terlihat bahwa distribusi dari titik-titik data kepribadian, profesionalisme, pengalaman mengajar dan kinerja menyebar. Grafik P-P Plot diatas menunjukan bahwa sebaran data menyebar disekitar garis diagonal, sehingga asumsi normalitas dipenuhi. Maka model regresi layak dipakai untuk memprediksi kinerja berdasarkan variabel independennya.

Berdasarkan gambar 2 dibawah terlihat bahwa grafik histogram memberikan pola distribusi normal tidak berpola distribusi melenceng (swewness) ke kiri atau ke kanan, maka model regresi memenuhi asumsi normalitas.

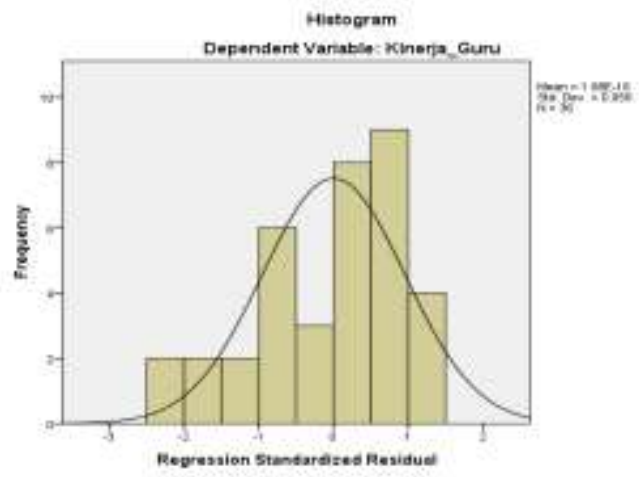

Gambar 2. Grafik Histogram

\subsection{Uji Multikolinearitas}

Metode untuk menguji ada tidaknya multikolinearitas dapat dilihat Tolerance Value dan Inflation Factor (VIF). Batas tolerance value adalah 0,10 atau nilai VIF adalah 10. Jika tolerance value $>0,10$ dan VIF $<10$ maka tidak terjadi multikolinearitas dan sebaliknya jika tolerance value $<0,10$ dan VIF $>10$ maka terjadi multikoleniaritas. Hasil pengolahan dapat dilihat pada tabel 5.14 berikut ini:

Tabel 2. Uji Multikolinearitas

Coefficients $^{\text {a }}$

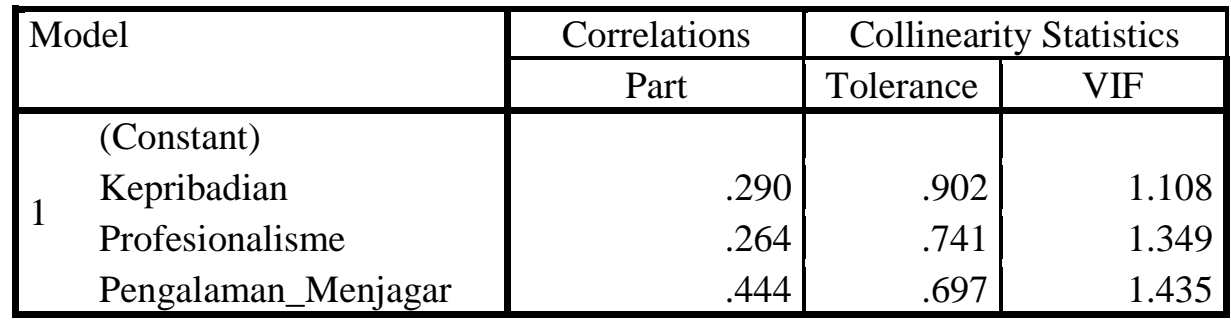

Berdasarkan output tabel 3 diatas, hasil perhitungan nilai tolerance menunjukan tidak ada variabel independen yang memiliki nilai tolerance kurang dari 0,10 yang berarti tidak ada korelasi antara variabel independen yang nilainya lebih dari $95 \%$. Hasil perhitungan nilai variance inflaction factor (VIF) juga menunjukan hal yang sama, yaitu tidak ada satu variabel independen yang memiliki nilai VIF lebih dari 10. Jadi dapat disimpulkan bahwa tidak ada multikolinieritas antar variabel independen dalam model regresi.

\subsection{Uji Heteroskedastisitas}

Uji heteroskedastisitas dilakukan untuk mengetahui apakah dalam sebuah model regresi terjadi ketidaksamaan varians dari residual suatu pengamatan ke pengamatan lain. Jika varians dari residual dari suatu pengamatan ke pengamatan lain tetap disebut heteroskedastisitas.

Menganalisis data dalam pengujian asumsi klasik ini, peneliti menggunakan Program Statistical Product and Service Solution (SPSS) for Windows dapat dilihat pada gambar 5.3 berikut ini: 


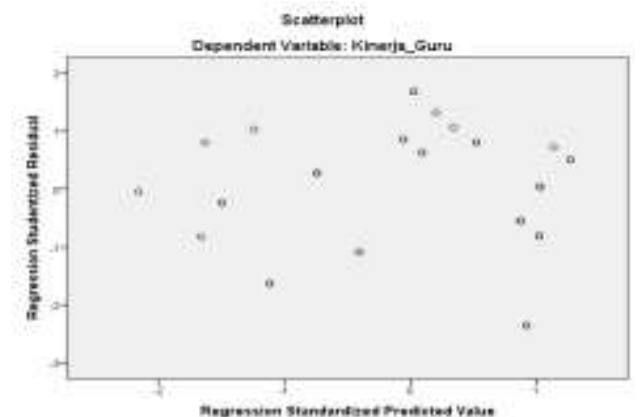

Gambar 3. Grafik scatterplot Uji Heteroskedastisitas

Dari gambar di atas menunjukkan bahwa diagram pencar tidak membentuk suatu pola atau acak, dengan demikian dapat dikatakan bahwa regresi tidak mengalami gangguan heteroskedastisitas pada model regresi sehingga model regresi layak dipakai untuk mengetahui
Kinerja Guru (Y) berdasarkan variabel bebasnya.

\subsection{Uji Autokorelasi}

Uji autokorelasi digunakan untuk melihat hubungan antara variabel bebas memiliki hubungan sama kuat atau tidak, dimana untuk melihat hubungan atau tidak hubungan secara autokorelasi dapat dilihat dengan Uji DurbinWatson (DW test)

Uji Durbin-Watson hanya digunakan untuk autokorelasi tingkat satu (first order autocorrelation) dan mensyaratkan adanya intercept (kostanta) dalam model regresi dan tidak ada variabel lain diantara variabel independent.

Tabel 3. Uji Durbin-Watson (DW test)

Model Summary ${ }^{b}$

\begin{tabular}{|c|c|c|c|c|}
\hline \multirow[t]{2}{*}{ Model } & \multicolumn{3}{|c|}{ Change Statistics } & \multirow[t]{2}{*}{ Durbin-Watson } \\
\hline & df1 & df2 & Sig. F Change & \\
\hline 1 & $3^{\mathrm{a}}$ & 32 & .000 & 1.863 \\
\hline
\end{tabular}

Sumber: Hasil Pengolahan SPSS Tahun 2020

Berdasarkan tabel 3 diatas diperoleh nilai Durbin-Watson sebesar 1.863. Nilai DurbinWatson menurut tabel dengan $n=36$ responden dan $\mathrm{K}=3$ (dalam hal ini adalah jumlah variabel bebas) didapat angka $\mathrm{dl}=1.295 \mathrm{dan} \mathrm{du}=1.653$. Oleh karena itu nilai DW hitung > du (1.863 > 1.732), maka dapat disimpulkan bahwa tidak terdapat autokorelasi dalam model regresi maka model layak untuk digunakan.

\section{Uji Hipotesis}

\subsection{Analisis Regresi Linier Berganda}

Analisis regresi linier berganda digunakan untuk mengetahui besar pengaruh kepribadian, profesionalisme dan pengalaman mengajar terhadap kinerja guru Madrasah Tsanawiyah Negeri 2 Mandailing Natal. Analisis dilakukan dengan menggunakan bantuan SPSS dengan output sebagai berikut:

Tabel 4. Regresi Linear Berganda

Coefficients $^{\mathrm{a}}$

\begin{tabular}{|ll|r|r|r|r|}
\hline \multicolumn{2}{|l|}{ Model } & \multicolumn{2}{|c|}{ Unstandardized Coefficients } & \multicolumn{1}{c|}{$\begin{array}{c}\text { Standardized } \\
\text { Coefficients }\end{array}$} & \multirow{2}{*}{$\mathrm{t}$} \\
\cline { 3 - 6 } & & \multicolumn{1}{|c|}{ B } & Std. Error & \multicolumn{1}{c|}{ Beta } & \\
\hline \multirow{2}{*}{1} & (Constant) & 6.145 & 2.732 & & 2.250 \\
& Kepribadian & .230 & .077 & .305 & 2.988 \\
& Profesionalisme & .246 & .090 & .307 & 2.728 \\
& Pengalaman_Menjagar & .506 & .110 & .532 & 4.580 \\
\hline
\end{tabular}

Sumber: Hasil Pengolahan SPSS Tahun 2020

Berdasarkan pengolahan data yang terlihat pada tabel output kolom kedua bagian B (Unstandardized Coefficients), diperoleh persamaan regresi linier berganda yaitu:

$$
y=a+b_{1} x_{1}+b_{2} x_{2}+b_{3} x_{3}+\varepsilon
$$

$Y=6.145+0.230 X_{1}+0.246 X_{2}+0.506 X_{3}+\varepsilon$

Dengan persamaan regresi linier berganda tersebut dapat dijelaskan bahwa:
1) Nilai konstanta adalah sebesar 6.145 hal ini menyatakan bahwa jika variable kepribadian, profesionalisme dan pengalaman mengajar diabaikan, maka nilai kinerja guru sebesar 6.145.

2) Koefisien regresi untuk variabel kepribadian sebesar 0.305 hal ini menunjukkan bahwa setiap kenaikan $1 \%$ faktor kepribadian maka 
akan meningkatkan kinerja guru sebesar $30,5 \%$.

3) Koefisien regresi untuk variabel profesionalisme sebesar 0.307 hal ini menunjukkan bahwa setiap kenaikan $1 \%$ faktor profesionalisme maka akan meningkatkan kinerja guru sebesar 30,7\%.

4) Koefisien regresi untuk variable pengalaman mengajar sebesar 0.532 hal ini menunjukkan bahwa setiap kenaikan $1 \%$ faktor Kepribadian maka akan meningkatkan kinerja guru sebesar 53,2\%.

\section{Evaluasi}

Untuk pengujian hipotesis yang diajukan diterima atau ditolak, digunakan uji $\mathrm{F}$ dengan ketentuan jika $\mathrm{F}_{\text {hitung }}>\mathrm{F}_{\text {tabel }}$ maka $\mathrm{H}_{0}$ ditolak dan $\mathrm{H}_{1}$ diterima, sebaliknya apabila $\mathrm{F}_{\text {hitung }} \leq$ $\mathrm{F}_{\text {tabel }}$ maka $\mathrm{H}_{0}$ diterima dan $\mathrm{H}_{1}$ ditolak.
Sedangkan pengujian secara parsial masingmasing variabel independen dimaksudkan untuk mengetahui apakah secara individual variabel kepribadian, profesionalisme dan pengalaman mengajar mempunyai pengaruh yang nyata atau tidak terhadap variabel kinerja guru. Untuk pengujian secara parsial digunakan uji $t$ dengan ketentuan jika $t_{\text {hitung }}>t_{\text {tabel }}$ maka $\mathrm{H}_{0}$ ditolak dan $\mathrm{H}_{1}$ diterima, sebaliknya apabila $\mathrm{t}_{\text {hitung }} \leq \mathrm{t}_{\text {tabel }}$ maka $\mathrm{H}_{0}$ diterima dan $\mathrm{H}_{1}$ ditolak.

\subsection{Uji Serempak}

Untuk mengetahui pengaruh kepribadian, profesionalisme dan pengalaman mengajar sebagai variabel bebas (X) terhadap kinerja guru sebagai variabel terikat (Y) di Madrasah Tsanawiyah Negeri 2 Mandailing Natal dapat dilihat pada tabel 5.17 berikut.

Tabel 5. Hasil Uji Serempak

ANOVA $^{\mathrm{a}}$

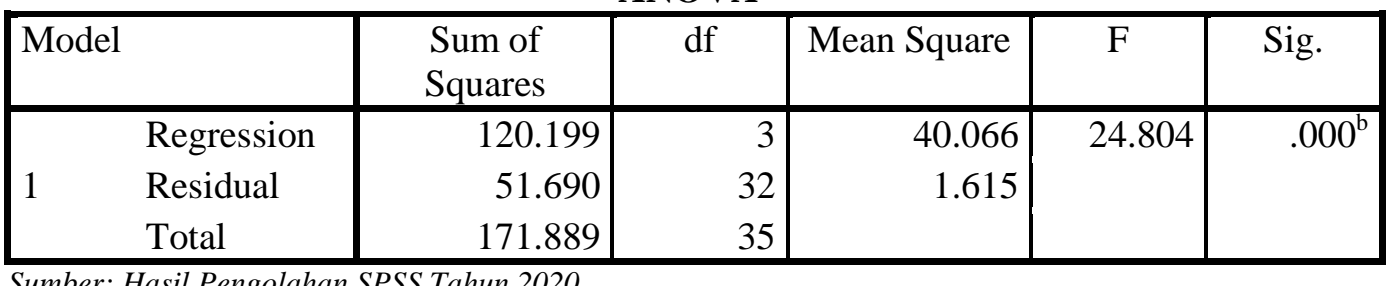

Dari tabel 5 diatas, diperoleh nilai $\mathrm{F}_{\text {hitung }}$ sebesar 24.804. Dengan menggunakan confidence interval $(\mathrm{CI}) 95 \%$ df $3: 36(\alpha=$ 0.05 ) maka dari tabel distribusi $F$ diperoleh nilai 2.87. Dengan demikian $\mathrm{F}_{\text {hitung }} 24.804>\mathrm{F}_{\text {tabel }}$ 2.87, maka $\mathrm{H}_{0}$ ditolak dan $\mathrm{H}_{1}$ diterima, artinya variabel kepribadian, profesionalisme serta pengalaman mengajar sebagai variabel bebas (X) berpengaruh signifikan terhadap variabel kinerja guru di Madrasah Tsanawiyah Negeri 2 Mandailing Natal.

Pada tabel 5 di atas terlihat nilai signifikansi sebesar $0.000^{\mathrm{b}}$ lebih kecil dari $\alpha=$ 0,05 , hal ini berarti bahwa variabel kepribadian, profesionalisme serta pengalaman mengajar sebagai variabel bebas memiliki pengaruh yang highly significant. Secara serempak variabel kepribadian, profesionalisme serta pengalaman mengajar menunjukkan pengaruh sangat nyata terhadap Kinerja Guru di Madrasah Tsanawiyah Negeri 2 Mandailing Natal.

\subsection{Uji Parsial}

Uji pengaruh variabel kepribadian, profesionalisme serta pengalaman mengajar secara parsial dapat dilihat pada tabel 5.19 berikut:

Tabel 6. Hasil Uji Parsial

Coefficients $^{\mathrm{a}}$

\begin{tabular}{|c|c|c|c|c|c|c|}
\hline \multirow{2}{*}{\multicolumn{2}{|c|}{ Model }} & \multicolumn{2}{|c|}{$\begin{array}{l}\text { Unstandardized } \\
\text { Coefficients }\end{array}$} & $\begin{array}{c}\text { Standardized } \\
\text { Coefficients }\end{array}$ & \multirow[t]{2}{*}{$\mathrm{t}$} & \multirow[t]{2}{*}{ Sig. } \\
\hline & & B & Std. Error & Beta & & \\
\hline \multirow{4}{*}{1} & (Constant) & 6.145 & 2.732 & & 2.250 & .031 \\
\hline & Kepribadian & .230 & .077 & .305 & 2.988 & .005 \\
\hline & Profesionalisme & .246 & .090 & .307 & 2.728 & .010 \\
\hline & Pengalaman_Menjagar & .506 & .110 & .532 & 4.580 & .000 \\
\hline
\end{tabular}

Sumber: Hasil Pengolahan SPSS Tahun 2020 
Dari tabel 6 diatas diperoleh nilai $t_{\text {hitung }}$ masing-masing variabel. Nilai $t_{\text {hitung }}$ tersebut selanjutnya dibandingkan dengan nilai $t_{\text {tabel }}$ pada tingkat kepercayaan $95 \%$ atau $\alpha=0,05$. Nilai $\mathrm{t}_{\text {tabel }}$ pada df 3:36 dengan $\alpha=0,05$ adalah 2.028.

Pengaruh parsial dari variabel kepribadian $\left(\mathrm{X}_{1}\right)$ diperoleh dengan nilai $\mathrm{t}_{\text {hitung }}$ sebesar 2.988, dengan demikian $t_{\text {hitung }}>t_{\text {tabel }}(2.988>2.028)$ dan nilai signifikan sebesar $0.005<0.05$, maka $\mathrm{H}_{0}$ diterima dan $\mathrm{H}_{1}$ ditolak, yang berarti bahwa variabel kepribadian $\left(\mathrm{X}_{1}\right)$ berpengaruh positif terhadap Kinerja Guru di Madrasah Tsanawiyah Negeri 2 Mandailing Natal. Hal ini berarti bahwa apabila kepribadian $\left(\mathrm{X}_{1}\right)$ meningkat, maka kinerja guru Madrasah Tsanawiyah Negeri 2 Mandailing Natal juga akan meningkat.

Pengaruh parsial dari variabel profesionalisme $\left(\mathrm{X}_{2}\right)$ diperoleh dengan nilai $\mathrm{t}_{\text {hitung }}$ sebesar 2.728 , dengan demikian $\mathrm{t}_{\text {hitung }}>$ $\mathrm{t}_{\text {tabel }}(2.728<2.028)$ dan nilai signifikan sebesar $0.010<0.05$, maka $\mathrm{H}_{0}$ ditolak dan $\mathrm{H}_{1}$ diterima, yang berarti bahwa variabel profesionalisme $\left(\mathrm{X}_{2}\right)$ berpengaruh positif dan signifikan terhadap kinerja guru Madrasah Tsanawiyah Negeri 2 Mandailing Natal. Hal ini berarti bahwa apabila profesionalisme $\left(\mathrm{X}_{2}\right)$ meningkat maka kinerja guru Madrasah Tsanawiyah Negeri 2 Mandailing Natal akan meningkat.

Tabel 7. Koefisien Determinasi

Model Summary ${ }^{b}$

\begin{tabular}{|c|c|c|c|c|c|c|}
\hline \multirow[t]{2}{*}{ Model } & \multirow[t]{2}{*}{$\mathrm{R}$} & \multirow[t]{2}{*}{ R Square } & \multirow{2}{*}{$\begin{array}{l}\text { Adjusted R } \\
\text { Square }\end{array}$} & \multirow{2}{*}{$\begin{array}{l}\text { Std. Error of } \\
\text { the Estimate }\end{array}$} & \multicolumn{2}{|c|}{ Change Statistics } \\
\hline & & & & & $\begin{array}{l}\text { R Square } \\
\text { Change }\end{array}$ & F Change \\
\hline 1 & $.836^{\mathrm{a}}$ & .699 & .671 & 1.271 & .699 & 24.804 \\
\hline
\end{tabular}

Sumber: Hasil Pengolahan SPSS Tahun 2020

Berdasarkan tabel 7 diatas diperoleh angka Adjusted R Square sebesar 0.671 atau $(67,1 \%)$. Hal ini menunjukkan bahwa persentase sumbangan pengaruh variabel independen (kepribadian, profesionalisme serta pengalaman mengajar) terhadap variabel dependen (kinerja guru) sebesar $67,1 \%$. Atau variasi variabel independen yang digunakan dalam model (kepribadian, profesionalisme serta pengalaman mengajar) mampu menjelaskan sebesar $67,1 \%$ variasi variabel dependen (Kinerja Guru). Sedangkan sisanya sebesar 32,9\% dipengaruhi atau dijelaskan oleh variabel lain yang tidak dimasukkan dalam model penelitian ini.

\section{Kesimpulan}

Pengaruh parsial dari variabel pengalaman mengajar $\left(X_{3}\right)$ diperoleh dengan nilai $t_{\text {hitung }}$ sebesar 4.580, dengan demikian $t_{\text {hitung }}>t_{\text {tabel }}$ $(4.580>2.028)$ dan nilai signifikan sebesar $0.000<0.05$, maka $\mathrm{H}_{0}$ ditolak dan $\mathrm{H}_{1}$ diterima, yang berarti bahwa variabel pengalaman mengajar $\left(\mathrm{X}_{3}\right)$ berpengaruh positif dan signifikan terhadap kinerja guru Madrasah Tsanawiyah Negeri 2 Mandailing Natal. Hal ini berarti bahwa apabila pengalaman mengajar $\left(\mathrm{X}_{3}\right)$ meningkat maka kinerja guru Madrasah Tsanawiyah Negeri 2 Mandailing Natal juga akan meningkat.

Berdasarkan hasil analisis diketahui bahwa nilai koefisien regresi yang paling tinggi adalah variabel pengalaman mengajar $\left(\mathrm{X}_{3}\right)$ sebesar 0.532 atau 53,2\%. Hal ini berarti bahwa pengalaman mengajar $\left(\mathrm{X}_{3}\right)$ berpengaruh lebih dominan terhadap kinerja guru Madrasah Tsanawiyah Negeri 2 Mandailing Natal.

\subsection{Uji Determinasi}

Selanjutnya berdasarkan nilai koefisien determinasi $\left(\mathrm{R}^{2}\right)$ diketahui besarnya pengaruh perubahan variabel kepribadian, profesionalisme serta pengalaman mengajar terhadap kinerja guru di Madrasah Tsanawiyah Negeri 2 Mandailing Natal sebagai berikut: 
dengan nilai $\mathrm{t}_{\text {hitung }}<\mathrm{t}_{\text {tabel }}(2.728<2.028)$ dan nilai signifikansi sebesar 0.010 .

4) Pengalaman mengajar berpengaruh positif dan signifikan terhadap kinerja guru Madrasah Tsanawiyah Negeri 2 Mandailing Natal dengan nilai $\mathrm{t}_{\text {hitung }}>\mathrm{t}_{\text {tabel }}(4.580>$ 2.028) dan nilai signifikansi sebesar 0.000 .

5) Angka Adjusted $R$ Square sebesar 0.671 atau $(67,1 \%)$ menunjukkan bahwa persentase sumbangan pengaruh variabel independen (kepribadian, profesionalisme dan pengalaman mengajar) terhadap variabel dependen (kinerja guru) sebesar 67,1\%.

\section{DAFTAR PUSTAKA}

Anwar Prabu Mangkunegara, (2004), Profesionalisme Guru, Rinela Cipta Jakarta.

Barnardin, H. John Joyce E.A. Ressul (2013), Human Resources, Mc Graw Hill, Inc, Singapore.

Cascio, Wayne F.,( (2006) Managing Human Resources: Productivity, Quality of Work Life, Profits, edition, New York, McGraw Hill

Darmini (2012), Pengaruh Profesionalisme Guru Dan Pengalaman Mengajar Terhadap Kinerja Guru SMP N Gombang Cawas Klaten, Jurnal (Surakarta, Universitas Muhammadiyah Surakarta)

Eliyanto dan Udik Budi Wiowo (2009), Pengaruh Jenjang Pendidikan, Pelatihan dan Pengalaman Mengajar Terhadap Profesionalisme, e-journal.

Fatah Syukur (2011), MSDM Guru, Andi Offset, Yogyakarta.

Faustino Cardoso Gomes (2011), Manajemen Sumber Daya Manusia, Andi Offset, Yogyakarta

Handoko (2012), Manajemen Personalia dan Sumber Daya Manusia, Edisi 2, BPFE, Yogyakarta

Hasibuan, Malayu, SP (208), Manajemen Sumber Daya Manusia, PT. Bumi Akasara Jakarta.

Husnan, Keldjrachman Suad, (2011), Manajemen Personalia, Edisi ke Empat, BPFE Yogyakarta

Ivancevich, G., and Koropaske, D., (2013) Organizations: Behavior, Stucture, Process, Singapore, McGraw Hill Company Jamil Suprihatiningrum, (2014), Guru Profesional : Pedoman Kinerja,
Kualifikasi, dan Kompetensi Guru, ArRuzz Media, Yogyakarta

Mangkunegara A. Anwar Prabu, Manajemen Sumber Daya Manusia, PT. Rosda Karya, Bandung

Manullang (2010), Manajemen Pengantar Ekonomi Sekolah, Edisi Revisi, Cetakan Ke Enam Belas, BPFE, Yogyakarta

Mulyasa (2013), Standar Kompetensi dan sertifikasi Guru, Remaja Rosdakarya, Bandung

Muhammad Zen, (2010), Kiat Sukses Mengikuti Sertifikasi Guru, Malang: Cakrawala Media Publisher

Nitisemito S Alex (2001), Manajemen Personalia, Cetakan Keempat, Ghalia, Jakarta.

Nur Muhsin dan Y. Sutomo (2016), Pengaruh Kepribadian Dan Motivasi Kerja Terhadap Kinerja Guru Dimoderasi Budaya Organisasi Pada Madrasah Tsanawiyah Swasta Kecamatan Winong Kabupaten Pati, https://www.unisbank.ac.id/ojs/index.php/pa scal/article/download/4695/1426

Pemerintah Republik Indonesia, (2011), Undang-Undang Republik Indonesia No. 20 Tahun 2011 tentang Sistem Pendidikan Nasional, Jakarta

Robbins, Stephen P., dan Judge, Timothy A., (2008) Perilaku Organisasi, Terjemahan Edisi Dua Belas, Jakarta, Salemba Empat

Santoso Singgih (2004), Buku Latihan SPSS Statistik Parametrik, PT. Alex Media Komputindo Gramedia Jakarta.

Sikula (2012). Dasar-Dasar Proses Belajar Mengajar. Bandung; Sinar Baru Algesindo

Slocum, Herriegel., (2009) "Principles of Organizational Behavior Tweith Edition”. Canada South western

Soetjipto. (2009). Profesi Keguruan. Jakarta: Rineka Cipta

Sugiyono(2015), Metode Penelitian Pendidikan: Pendekatan Kuantitatif

Kualitatif dan R\&D, Alfabeta, Bandung.

Sumardi (2016), Pengembangan

Profesionalisme Guru Berbasis MGMP :

Model dan Implementasinya untuk Meningkatkan Kinerja Guru, Depublish, Yogyakarta

Supardi (2014), Kinerja Guru, Raja Grafindo Persada, Jakarta

Susianti, (2016) Pengaruh Kepribadian Dan Profesionalisme Guru Terhadap Kinerja Guru SMP Negeri Di Kecamatan Simpang 
Alahan Mati. Masters thesis, Universitas Terbuka

Tabrani Rusyan dkk. (2010) Upaya Meningkatkan Budaya Kinerja Guru, Cianjur: CV. Dinamika Karya Cipta

Triton PB (2006), SPSS 12.00 Terapan Riset Statistik Parametrik, Andi Yogyakarta. 